\title{
A new species of freshwater crab of the genus Qianguimon Huang, 2018 (Decapoda: Brachyura: Potamidae) from Guangxi, Southern China
}

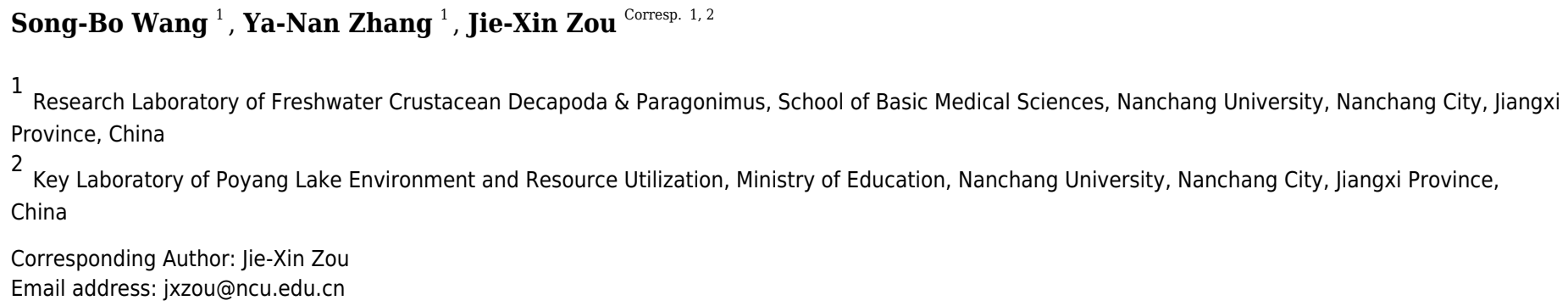

${ }^{1}$ Research Laboratory of Freshwater Crustacean Decapoda \& Paragonimus, School of Basic Medical Sciences, Nanchang University, Nanchang City, Jiangxi Province, China

${ }^{2}$ Key Laboratory of Poyang Lake Environment and Resource Utilization, Ministry of Education, Nanchang University, Nanchang City, Jiangxi Province, China

Corresponding Author: Jie-Xin Zou

Email address: jxzou@ncu.edu.cn

A new species of freshwater crab of the genus Qianguimon Huang, 2018, is described from Guangxi Zhuang Autonomous Region, southern China. It can be distinguished from congeners by the following characters: male first gonopods bent inward at about $45^{\circ}$ at base of terminal segment, carapace regions distinct and rugged and the female vulva opening inwards and downwards. In addition, molecular evidence derived from the $16 \mathrm{~S}$ rRNA gene supported the species described in this study as a new species of Qianguimon. 


\title{
1 A new species of freshwater crab of the genus Qianguimon
}

2 Huang, 2018 (Decapoda: Brachyura: Potamidae) from

3 Guangxi, Southern China

4

\author{
Song-Bo Wang ${ }^{1}$, Ya-Nan Zhang ${ }^{1}$, Jie-Xin Zou ${ }^{1,2}$ \\ ${ }^{1}$ Research Laboratory of Freshwater Crustacean Decapoda \& Paragonimus, School of Basic Medical \\ Sciences, Nanchang University, Nanchang City, Jiangxi Province, China \\ ${ }^{2}$ Key Laboratory of Poyang Lake Environment and Resource Utilization, Ministry of Education, \\ Nanchang University, 1299 Xuefu Avenue, Nanchang City, Jiangxi Province, China
}

Corresponding Author:

Jie-Xin Zou ${ }^{1}$

1299 Xuefu Avenue, Nanchang City, Jiangxi Province, People's Republic of China

Email address: jxzou@ncu.edu.cn

\section{Abstract}

A new species of freshwater crab of the genus Qianguimon Huang, 2018, is described from Guangxi Zhuang Autonomous Region, southern China. It can be distinguished from congeners by the following characters: male first gonopods bent inward at about $45^{\circ}$ at base of terminal segment, carapace regions distinct and rugged and the female vulva opening inwards and downwards. In addition, molecular evidence derived from the 16S rRNA gene supported the species described in this study as a new species of Qianguimon.

\section{Introduction}

China is the global centre of freshwater crab diversity, it has the richest number of freshwater crab species in the world, with more than 300 species from 48 genera and 2 subfamilies with many more to be discovered (Dai, 1999; Yeo et al., 2007; Cumberlidge et al., 2011; Chu et al., 2018; Chu, Wang \& Sun, 2018; Huang, Shih \& Ahyong, 2018; Huang, Wong \& Ahyong, 2018; Naruse, Chia \& Zhou, 2018; Wang, Huang \& Zou, 2019; Wang, Zhou \& Zou, 2019). And more than 90 percent of China's freshwater crab species are distributed in the "China" freshwater zoogeographical subregion (Chu et al., 2018; Huang, Ebach \& Ahyong, 2020).

Qianguimon is a genus established by Huang, 2018, with four species have been reported at present. The type species $Q$. aflagellum was originally described as Isolapotamon aflagellum by Dai et al. (1980) from Zhaoping, Guangxi Zhuang Autonomous Region. Afterwards, Huang (2018) recorded two additional localities for this species from Mengshan and Chengzhong, Guangxi, and placed it in the genus Qianguimon. Huang (2018) also reported another two new species of this genus: Q. splendidum from Yanghe, Guangxi and Q. elongatum from Leishan, 
Guizhou Province. Wang, Huang \& Zou (2019) subsequently described the fourth species: $Q$. rongxianense from Rong, Guangxi. The prominent feature of this genus is the boot-shaped terminal segment of the male first gonopod (Huang, 2018; Wang, Huang \& Zou, 2019). They have a broad altitude range, from close to sea level to over $1,000 \mathrm{~m}$, and can be found at altitudes as high as 1,500 $\mathrm{m}$ (Huang, 2018).

Species exploration is ongoing. In a joint research survey with Chao Huang and Si-Ying Mao, we discovered a new species of the genus Qianguimon from Yuzhou District, Yulin City, Guangxi Zhuang Autonomous Region, southern China during. It is herein described as a new species.

\section{Material \& Methods}

Material examined. Specimens were collected from Yuzhou District of Yulin City in Guangxi Zhuang Autonomous Region by Song-Bo Wang, preserved in 95\% ethanol; and deposited at the Department of Parasitology of the Medical College of Nanchang University, Jiangxi, China (NCU MCP), National Tropical Disease Research Center, Shanghai, China (TDRC), Zoological Reference Collection of the Raffles Museum of Biodiversity Research, National University of Singapore, Singapore (ZRC), Sun Yat-sen Museum of Biology, Sun Yat-sen University, Guangzhou, China (SYSBM). Some of the comparative materials were also deposited at the Sun Yat-sen Museum of Biology, Sun Yat-sen University, Guangzhou, China (SYSBM). Carapace width and length were measured in millimeters. The abbreviations G1 and G2 refer to the male first and second gonopods, respectively. The terminology used herein primarily follows that of Dai (1999) and Davie et al. (2015).

Molecular analyses. Muscle tissue was excised from chelipeds, total genomic DNA was extracted from the tissue using the Omega Tissue Kit following the manufacturer's protocol. Then, the 16S rRNA gene was amplified using polymerase chain reaction (PCR) with the primers 1471 (5'-CCTGTTTANCAAAAACAT-3') and 1472 (5'AGATAGAAACCAACCTGG-3') (Crandall and Fitzpatrick, 1996). The PCR conditions were as follows: denaturation for $50 \mathrm{~s}$ at $94{ }^{\circ} \mathrm{C}$, annealing for $40 \mathrm{~s}$ at $52^{\circ} \mathrm{C}$ and extension for $1 \mathrm{~min}$ at $72^{\circ} \mathrm{C}$ ( 33 cycles), followed by a final extension for $10 \mathrm{~min}$ at $72{ }^{\circ} \mathrm{C}$. The PCR products were purified and sequenced using an $\mathrm{AB}$ I 3730 automatic sequencer.

We performed the molecular analysis with the mitochondrial $16 \mathrm{~S}$ rRNA gene fragment. In total, 26 species of 18 genera were used to construct phylogenetic trees (Table 1). Sequences were aligned using MAFFT ver.7.215 (Katoh \& Standley, 2013) based on the G-INS-I method, and the conserved regions were selected with Gblocks 0.91b (Castresana, 2000) using the default settings. The best-fitting model for Bayesian Inference (BI) analysis was determined by MrModeltest ver.2.2 (Nylander, 2005), selected by the Akaike information criterion (AIC). The obtained model was GTR+I+G (Tavaré, 1986). MrBayes ver.3.2.6 (Ronquist et al., 2012) was employed to perform the BI analysis, and four Monte Carlo Markov Chains of 2,000,000 generations were run with sampling every 1,000 generations. The first 500,000 generations were 
79

80

81

82

83

84

85

86

87

88

89

90

91

92

93

94

95

96

97

98

99

100

101

102

103

104

105

106

107

108

109

110

111

112

113

114

115

116

117

118

discarded as burn-in. The best evolutionary model for Maximum Likelihood (ML) analysis was $\mathrm{HKY}+\mathrm{I}+\mathrm{G}$ (Hasegawa, Kishino \& Yano, 1985), determined by MEGA ver.X.0 (Kumar et al. 2018) based on the Bayesian information criterion (BIC). The ML tree was built based on 1000 bootstrap replicates in MEGA ver.X.0 (Kumar et al. 2018). The pairwise estimates of Kimura 2parameter (K2P) distances (Kimura, 1980) among the five species of Qianguimon were calculated using MEGA ver.X.0 (Kumar et al. 2018).

The electronic version of this article in portable document format will represent a published work according to the International Commission on Zoological Nomenclature (ICZN), and hence the new names contained in the electronic version are effectively published under that Code from the electronic edition alone. This published work and the nomenclatural acts it contains have been registered in ZooBank, the online registration system for the ICZN. The ZooBank LSIDs (Life Science Identifiers) can be resolved and the associated information viewed through any standard web browser by appending the LSID to the prefix http://zoobank.org/. The LSID for this publication is: urn:lsid:zoobank.org:pub:7BFE0C18-76EE-483C-9B5F-C0143C5B6A16. The online version of this work is archived and available from the following digital repositories: Peer J, PubMed Central, and CLOCKSS.

\section{Results}

Systematics

\section{Family Potamidae Ortmann, 1896 \\ Qianguimon Huang, 2018}

\section{Qianguimon yuzhouense n. sp. (Figs. 1-4)}

urn:1sid:zoobank.org:act: A785F440-CFB0-42A8-9304-7433E6FE57A8

Material examined. Holotype: male $(21.3 \times 18.2 \mathrm{~mm})($ NCU MCP 415701), Winding road beside Hanshan Temple on Gui Mountain (2241'5.18' 'N 110¹2'58.56' 'E, $246 \mathrm{~m}$ asl.), Yuzhou District, Yulin City, Guangxi Zhuang Autonomous Region, China, coll. Song-Bo Wang, Jie-Xin Zou, Chao Huang, Si-Ying Mao, 18 Dec. 2018. Paratypes: 2 males $(18.7 \times 16.0 \mathrm{~mm}, 20.3 \mathrm{~mm} \times$ $16.6 \mathrm{~mm}$ ) (TDRC 002003, ZRC 2019.1662), 2 females $(14.5 \times 12.3 \mathrm{~mm}, 14.6 \times 12.1 \mathrm{~mm})(\mathrm{NCU}$ MCP 415703, TDRC 002004), same data as holotype. Others: 5 males $(16.0 \times 13.8 \mathrm{~mm}, 15.7 \times$ $13.4 \mathrm{~mm}, 22.6 \times 18.9 \mathrm{~mm}, 19.5 \times 16.9 \mathrm{~mm}, 14.1 \times 11.5 \mathrm{~mm}$; NCU MCP 415704, NCU MCP 415705, SYSBM 001977, SYSBM 001978, SYSBM 001979) and 1 female $(15.8 \times 13.2 \mathrm{~mm})$ (SYSBM 001980), same data as holotype.

Comparative material. Qianguimon rongxianense Wang, Huang \& Zou, 2019: Holotype: 1 male (15.2 × $12.8 \mathrm{~mm}$ ) (NCU MCP 118401), Sixian Village, Licun Town, Rong County, Yulin City, Guangxi Zhuang Autonomous Region, small stream, coll. Ye-Song Cheng, August 23, 
119

120

121

122

123

124

125

126

127

128

129

130

131

132

133

134

135

136

137

138

139

140

141

142

143

144

145

146

147

148

149

150

151

152

153

154

155

156

157

2007; Paratype, 1 female (allotype) $(20.4 \times 16.0 \mathrm{~mm})$ (NCU MCP 118403), same data as holotype. Qianguimon aflagellum Huang, 2018: 1 male $(19.4 \times 15.8 \mathrm{~mm})($ SYSBM 001403), Wuzhou, Mengshan, Guangxi Province, shallow creek, April 2014 coll. C. Huang; 1 female $(22.7 \times 18.0 \mathrm{~mm})($ SYSBM 001404), same data as above [photos examined]. Qianguimon elongatum Huang, 2018: Holotype, 1 male $(22.0 \times 16.8 \mathrm{~mm})($ SYSBM 001421), Leishan County, Qiandongnan Miao and Dong Autonomous Prefecture, Guizhou Province, mud burrows at the side of hillstreams, July 2013, coll. C. Huang; Paratypes, 1 female (allotype), $(29.0 \times 21.5 \mathrm{~mm}) \mathrm{SYSBM}$ 001423, same data as holotype [photos examined]. Qianguimon splendidum Huang, 2018: Holotype, 1 male $(27.8 \times 21.1 \mathrm{~mm})($ SYSBM 001597), Yanghe County, Liuzhou City, Guangxi Zhuang Autonomous Region, mud burrows at the side of hillstreams, September 2015, coll. C. Huang; Paratype, 1 female (allotype) $(30.8 \times 23.0 \mathrm{~mm})$ (SYSBM 001598), same data as holotype [photos examined].

Diagnosis. Carapace broader than long, regions distinct, anterolateral regions rugose; cervical groove and H-shaped groove deep, distinct; epigastric cristae conspicuous, postorbital cristae sharp. External orbital angle narrowly triangular, separated from anterolateral margin by gap; epibranchial teeth distinct; anterolateral margin lined with conspicuous granules. Third maxilliped merus median depression indistinct, exopod with vestigial flagellum. Chelipeds slightly unequal; outer surfaces of chelae smooth; fingers with very small gap when closed. Male pleon narrowly triangular, lateral margins gently concave; telson triangular, somite 6 transversely trapeziform. Male sterno-pleonal cavity very deep, median longitudinal suture of sternites 7/8 deep and relatively long. G1 very slender, terminal segment boot-shaped, distinctly sinuous, tip of terminal segment exceeding sternites $4 / 5$ suture. Female vulva reaching sternites $5 / 6$ suture, with opening directed inward at an angle of $45^{\circ}$.

Description. Carapace sub-quadrate, 1.1-1.2 times as broad as long (mean =1.18); regions distinct, dorsal surface with pits and scattered setae; anterolateral region wrinkled (Figs. 1A and 3A). Branchial regions slightly swollen. Cervical groove very deep, distinct; H-shaped groove between gastric and cardiac regions deep and distinct (Figs. 1A and 3A). Epigastric cristae conspicuous, separated by narrow gap; postorbital cristae sharp, not fused with epigastric cristae, nearly reaching the anterolateral margin (Figs. 1A and 3A). Front distinctly deflexed, margin ridged in dorsal view, medially concave (Figs. 1A and 3A). External orbital angle narrowly triangular, very sharp, margins smooth and without any granules, separated from anterolateral margin by small distinct V-shaped gap; epibranchial teeth small, distinct, granular (Figs. 1A and 3A). Anterolateral margin distantly cristate, lined with approximately 16 granules, lateral part bent inward; posterolateral surface smooth, with inconspicuous oblique striae, converging towards posterior carapace margin (Figs. 1A and 3A). Orbits medium size; supraorbital, infraorbital margins cristate, smooth and without granules (Fig. 1B). Sub-orbital regions covered with scattered rounded granules; sub-hepatic regions and pterygostomial regions covered

PeerJ reviewing PDF | (2020:02:45664:2:0:NEW 19 Apr 2020) 
158

159

160

161

162

163

164

165

166

167

168

169

170

171

172

173

174

175

176

177

178

179

180

181

182

183

184

185

186

187

188

189

190

191

192

193

194

195

196

197

numerous large granules (Fig. 1B). Epistome posterior margin narrow; median lobe triangular, lateral margins oblique (Fig. 1B).

Third maxilliped merus about 1.3 times as broad as long, trapezoidal, median depression indistinct; ischium about 1.5 times as long as broad, rectangular, with distinct median sulcus; exopod reaching approximately $1 / 5$ of merus length, with vestigial flagellum; dactylus not reaching the upper edge of ischium (Fig. 1C).

Chelipeds slightly unequal (Fig. 2A). Merus cross-section trigonal, with inner-lower margin crenulated (Fig. 2A). Carpus surface weakly wrinkled, with prominent sharp spine at inner-distal margin (Fig. 1A). Outer surfaces of chelae pitted, palm of larger chela about 1.2 times as long as high (Fig. 2A). Movable finger approximately as long as the immovable finger; inner margin of fingers with numerous round and blunt teeth; fingers forming inconspicuous gap when closed (Fig. 2A).

Male thoracic sternum generally smooth, pitted (Fig. 2B). Sternites 1, 2 completely fused to form triangular structure; sternites 2, 3 separated by obvious suture; sternites 3, 4 fused (Fig. 2A). Male sterno-pleonal cavity very deep, nearly reaching imaginary line connecting mid-length of cheliped coxae (Fig. 2C). Median longitudinal suture of sternites 7, 8 deep and relatively long; male pleonal locking tubercle inconspicuous, round, on posterior third of sternite 5 (Fig. 2C). Female vulva reaching sternites 5/6, reaching proximal three-quarters width of sternite 6; upper and lower margin flat without any swelling; opening directed inward at about an angle of $45^{\circ}$ (Fig. 3B).

Male pleon narrowly triangular, lateral margins gently concave; telson triangular, lateral margins oblique, straight; somite 6 transversely trapeziform, about 2.1 times as broad as long (Fig. 2B); somites 3-5 trapezoidal, gradually decreasing in width, increasing in length, lateral margins oblique; somites 1 and 2 sub-rectangular, very wide, the former flatter, reaching to bases of coxae of fourth ambulatory legs (Fig. 2D).

Ambulatory legs slender; the second pair longest and last pair shortest (Fig. 1A). Merus longest, without subdistal spine or tooth; carpus stout, dorsal margin with cristae (Fig. 1A). The fourth leg propodus about 1.9 times as long as broad, slightly shorter than dactylus; dactylus sharp, with several spines and numerous setae on the surface (Fig. 2E).

G1 very slender, dorsal and ventral surface smooth, lateral margin without seta, terminal segment boot-shaped, distinctly sinuous, bend inward at a $45^{\circ}$ angle medially, with blunt subdistal projection (Figs. 4A-D and 5A); tip of terminal segment exceeding sternites 4/5 suture (Fig. 2D); subterminal segment about 2.0 times as long as terminal segment. G2 elongate, almost equal to G1 in length; basal segment about 2.2 times length of distal segment, basal segment subovate (Fig. 4E). Groove for G2 located medially on the ventral side of G1 subterminal segment, thin setae on distal regions of G1 subterminal segment (Fig. 4A).

Remarks. The new species is similar to other species Qianguimon, in its carapace broader than long, postorbital and epigastric cristae visible; exopod of the third maxilliped with short or no flagellum, male pleon triangular; G1 generally slender, terminal segment boot-shaped with sub- 
198

199

200

201

202

203

204

205

206

207

208

209

210

211

212

213

214

215

216

217

218

219

220

221

222

223

224

225

226

227

228

229

230

231

232

233

234

235

236

237

distal projection; vulvae medium-sized and reaching proximal three-quarters width of sternite 6 . But Q. yuzhouense n. sp. can be differentiated from congeners by its regions distinct and dorsal surface rugged, narrowly triangular and sharp external orbital angle, blunt and broadly triangular epibranchial tooth, G1 very slender and bent inward at about $45^{\circ}$ at base of terminal segment, tip exceeding sternites $4 / 5$ suture in situ, female vulva opening inward at a $45^{\circ}$ angle. Other differences are listed in Table 2 and Figure 5.

Etymology. The new species is named after the type locality, Yuzhou District, Yulin City, Guangxi Zhuang Autonomous Region, China.

Living color. Most of the carapace is dark brown. The chelipeds are brown to orange, while the ambulatory legs are brown. The overall color is consistent with the surrounding environment. (Figs. 6A-B)

Ecology. This species was found in a stream next to a mountain road. The stream has no obvious flowing water, and has lush weeds growing in it. We found the crab burrows by removing the weeds. The burrows are sandy and without much soil. We found the crabs after digging about $10 \mathrm{~cm}$ into the burrows. (Figs. 6C-D)

\section{Phylogenetic analyses}

In this study, we obtained the 16S rRNA molecular data of three specimens collected from Yuzhou District, Yulin City, Guangxi Zhuang Autonomous Region, China. The alignment sequences were downloaded from GenBank and include 26 species from 18 genera of the subfamily Potamidae Ortmann, 1896 from Asia. The access numbers can be found in Table 1 . We used the BI and ML methods to construct the phylogenetic tree. The topological structure of the trees showed a high degree of consistency (Fig. 7). The three mitochondrial 16S rRNA gene fragments of the new species are very close genetically, with the pairwise genetic distances zero (Table 3), which indicates that they are sequences from the same species and are consistent with the results of the morphological study. The new species are clustered together with $Q$.

rongxianense, $Q$. aflagellum, Q. elongatum and $Q$. splendidum, and form an independent branch in the clade "Southern China" (Huang, Ebach \& Ahyong, 2020), indicating that the five species are congeners of the genus Qianguimon. The minimum interspecific pairwise K2P genetic distances of the new species and other congeners is 0.037507 (Table 3 ).

\section{Discussion}

Qianguimon yuzhouense n. sp. has the diagnostic features of Qianguimon, such as visible postorbital and epigastric cristae and male first gonopod generally slender with boot-shaped terminal segment (Huang, 2018). In this study, we collected mitochondrial 16S rRNA gene molecular data for all species of the genus, and based on this, established BI and ML phylogenetic trees. Phylogenetic analysis showed that the five species of the genus formed an 
238

239

240

241

242

243

244

245

246

247

248

249

250

251

252

253

254

255

256

257

258

259

260

261

262

263

264

265

266

267

268

269

270

271

272

273

274

275

276

independent branch. Both phylogenetic tree and genetic distances suggest that $Q$. yuzhouense is a new species. There are three clades within Qianguimon, however, support for these clades is not high. Considering the shared generic characters of these species, we believe that these species all belong to the same genus. The new species is found in Yuzhou District of Yulin City, Guangxi Zhuang Autonomous Region, which is within the distribution of Qianguimon. The other four reported species of this genus are all distributed in southern Guizhou Province or eastern Guangxi Zhuang Autonomous Region (Huang, 2018; Wang, Huang \& Zou, 2019). In summary, the species reported in this paper is a new species of Qianguimon that is supported by molecular data, morphology and biogeography.

\section{Conclusions}

In this paper, we reported a new species of freshwater crab from Yuzhou District, Yulin City, Guangxi Zhuang Autonomous Region, China. We found that it fits well within the definition of Qianguimon Huang, 2018, morphologically, and our molecular analysis also supports it as a new species of the genus Qianguimon.

\section{Acknowledgments}

We would like to thank Chao Huang and Si-Ying Mao for locating the crabs, assisting us in collecting specimens and for taking photos of live specimens for us to use. We also would like to thank Milan Koch and other two anonymous reviewers for greatly improving this manuscript.

\section{References}

Castresana J. 2000. Selection of conserved blocks from multiple alignments for their use in phylogenetic analysis. Molecular Biology and Evolution 17(4):540-552 DOI 10.1093/oxfordjournals.molbev.a026334.

Chu KL, Ma XP, Zhang ZW, Wang PF, Lü LN, Zhao Q, Sun HY. 2018. A checklist for the classification and distribution of China's freshwater crabs. Biodiversity Science 26 (3):274282 DOI 10.17520/biods.2018062 [in Chinese with English summary].

Chu KL, Wang PF, Sun HY. 2018. A new genus and species of primary freshwater crab and a new species of Artopotamon Dai \& Chen, 1985 (Crustacea, Brachyura, Potamidae) from western Yunnan, China. Zootaxa 4422:115 DOI 10.11646/zootaxa.4422.1.7.

Chu KL, Zhou LJ, Sun HY. 2017. A new genus and new species of freshwater crab (Decapoda: Brachyura: Potamidae Ortmann, 1896) from Yunnan Province, China. Zootaxa 4286(2):241-253 DOI 10.11646/zootaxa.4286.2.7.

Crandall KA, Fitzpatrick JFJ. 1996. Crayfish molecular systematics: using a combination of procedures to estimate phylogeny. Systematic Biology 45:1-26.

Cumberlidge N, Ng PKL, Yeo DCJ, Naruse T, Meyer KS, Esser LJ. 2011. Diversity, endemism and conservation of the freshwater crabs of China (Brachyura: Potamidae and Gecarcinucidae). Integrative Zoology 6(1):45-55 DOI 10.1111/j.1749-4877.2010.00228.x. 
277

278

279

280

281

282

283

284

285

286

287

288

289

290

291

292

293

294

295

296

297

298

299

300

301

302

303

304

305

306

307

308

309

310

311

312

313

314

315

Dai AY. 1999. Fauna Sinica (Arthropoda. Crustacea. Malacostraca. Decapoda. Parathelphusicae. Potamidae). Beijing: Science Press [in Chinese with English summary].

Dai AY, Song YZ, Li LL, Liang PX. 1980. New species and new record of freshwater crabs from Guangxi. Acta Zootaxonomica Sinica 5(4):369-376.

Davie PJF, Guinot D, Ng PKL. 2015. Anatomy and functional morphology of Brachyura. In: Castro P, Davie PJF, Guinot D, Schram FR, von Vaupel Klein JC (Eds) Treatise on Zoology - Anatomy, Taxonomy, Biology. The Crustacea Volume 9C-I. Decapoda: Brachyura, 1049-1130 DOI 10.1163/9789004190832.

Hasegawa M, Kishino H, Yano T. 1985. Dating of the human-ape splitting by molecular clock of mitochondrial DNA. Journal of molecular evolution 22(2):160-174.

Huang C. 2018. Revision of Yarepotamon Dai \& Türkay, 1997 (Brachyura: Potamidae), freshwater crabs endemic to southern China, with descriptions of two new genera and four new species. Journal of Crustacean Biology 38:173-189 DOI 10.1093/ jcbiol/rux120.

Huang C, Ebach MC, Ahyong ST. 2020. Bioregionalisation of the freshwater zoogeographical areas of mainland China. Zootaxa 4742: 271-298 DOI 10.11646/zootaxa.4742.2.3.

Huang C, Shih HT, Ahyong ST. 2018. Two new genera and two new species of narrow-range freshwater crabs from Guangdong, China (Decapoda: Brachyura: Potamidae). Journal of Crustacean Biology 38(5):614-624 DOI 10.1093/jcbiol/ruy050.

Huang C, Shih HT, Ng PKL. 2017. A new genus and new species of Potamidea (Crustacea: Decapoda: Brachyura: Potamoidae), the first stygomorphic cave crab known from china and east Asia. Zootaxa 4232:71-84 DOI 10.11646/zootaxa.4232.1.5.

Huang C, Wong KC, Ahyong ST. 2018. The freshwater crabs of Macau, with the description of a new species of Nanhaipotamon Bott, 1968 and the re-description of Nanhaipotamon wupingense Cheng, Yang, Zhong \& Li, 2003 (Crustacea, Decapoda, Potamidae). ZooKeys 810:91-111 DOI 10.3897/zookeys.810.30726.

Katoh K, Standley DM. 2013. MAFFT multiple sequence alignment software version 7: Improvements in performance and usability. Molecular Biology and Evolution 30:772-780 DOI 10.1093/molbev/mst010.

Kimura M. 1980. A simple method for estimating evolutionary rate of base substitutions through comparative studies of nucleotide sequences. Journal of Molecular Evolution 16:111-120.

Kumar S, Stecher G, Li M, Knyaz C, Tamura K. 2018. MEGA X: Molecular evolutionary genetics analysis across computing platforms. Molecular Biology and Evolution 35:15471549.

Naruse T, Chia JE, Zhou XM. 2018. Biodiversity surveys reveal eight new species of freshwater crabs (Decapoda: Brachyura: Potamidae) from Yunnan Province, China. PeerJ 6: e5497 DOI 10.7717/peerj.5497.

Nylander JAA. 2005. MrModeltest, version 2.2. Program distributed by the author. Evolutionary Biology Centre, Uppsala University, Uppsala, Sweden. 
Ronquist F, Teslenko M, van der Mark P, Ayres DL, Darling A, Hohna S. 2012. MrBayes 3.2: Efficient Bayesian phylogenetic inference and model choice across a large model space. Systematic Biology 61:539-542 DOI 10.1093/sysbio/sys029.

Shih HT, Yeo DCJ, Ng PKL. 2009. The collision of the Indian plate with Asia: molecular evidence for its impact on the phylogeny of freshwater crabs (Brachyura: Potamidae). Journal of Biogeography 36:703-719 DOI 10.1111/j.1365-2699.2008.02024.x.

Shih HT, Huang C, Ng PKL. 2016. A re-appraisal of the widely-distributed freshwater crab genus Sinopotamon Bott, 1967, from China, with establishment of a new genus (Crustacea: Decapoda: Potamidae). Zootaxa 4138:309. DOI 10.11646/zootaxa.4138.2.5.

Tavaré S. 1986. Some probabilistic and statistical problems in the analysis of DNA sequences. Lectures on mathematics in the life sciences 17(2):57-86.

Wang SB, Huang C, Zou JX. 2019. Description of a new species of freshwater crab of the genus Qianguimon Huang, 2018 (Crustacea: Decapoda: Brachyura: Potamidae) from Yulin, Guangxi, southern China. Zoological Studies 58:31 DOI 10.6620/ZS.2019.58-31.

Wang SB, Zhou XM, Zou JX. 2019. A new species of freshwater crab of the genus Mediapotamon Türkay \& Dai, 1997 (Crustacea, Decapoda, Brachyura, Potamidae) from Guizhou, China. ZooKeys 873:9-23 DOI 10.3897/zookeys.873.36702.

Yeo DCJ, Ng PKL, Cumberlidge N, Magalhães C, Daniels SR, Campos MR. 2007. Global diversity of crabs (Crustacea: Decapoda: Brachyura) in freshwater. Hydrobiologia 595:275286. 
Figure 1

Qianguimon yuzhouense n. sp. Holotype male $(21.3 \times 18.2 \mathrm{~mm})($ NCU MCP 415701).

(A) overall habitus; (B) frontal view of the cephalothorax; (C) left third maxilliped. Scales $=5$ mm. Photo credit: Song-Bo Wang. 


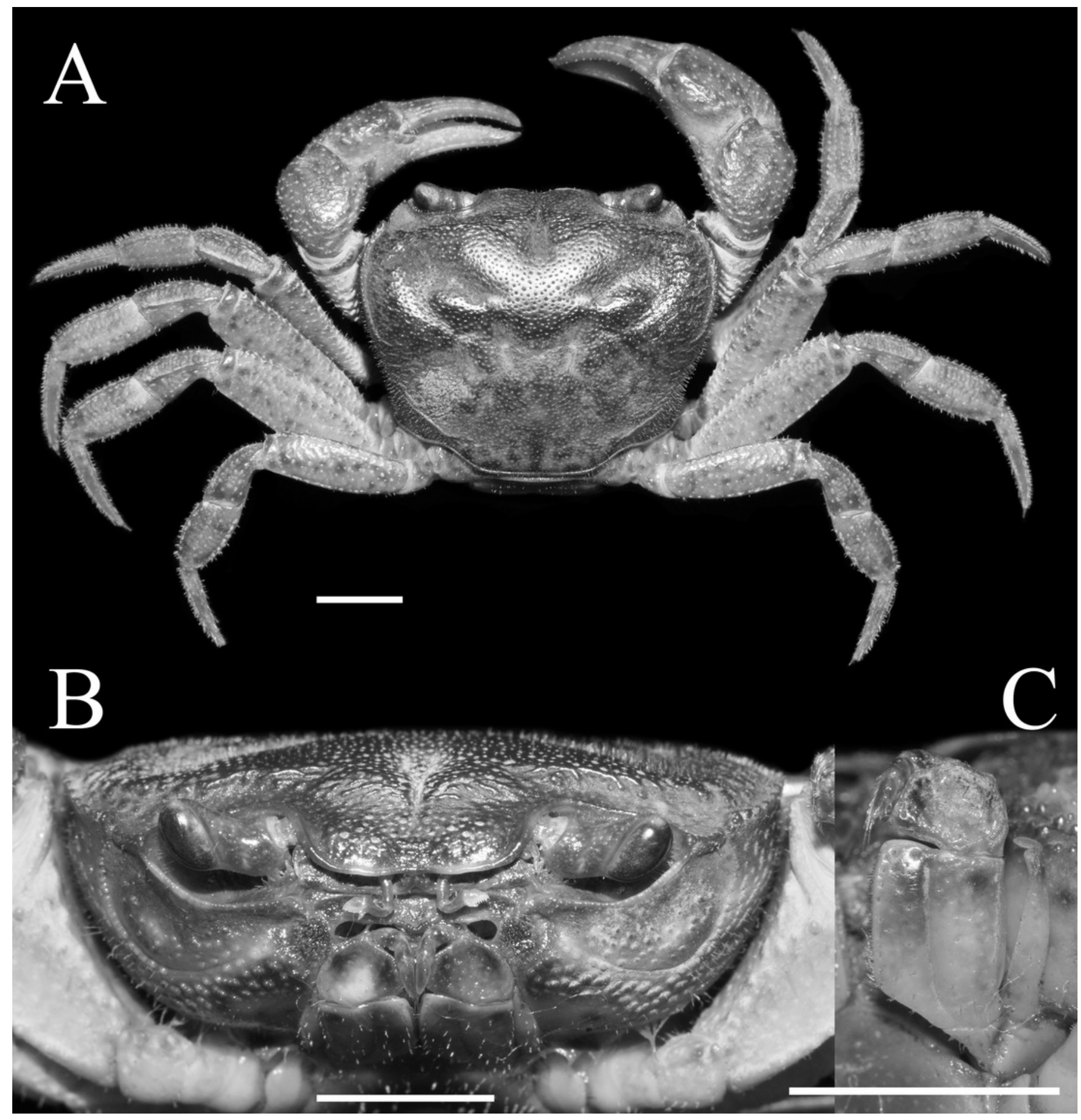


Figure 2

Qianguimon yuzhouense n. sp. Holotype male $(21.3 \times 18.2 \mathrm{~mm})($ NCU MCP 415701$)$.

(A) outer view of chelipeds; (B) ventral view of anterior thoracic sternum, telson, and male pleonal somites 4-6; (C) ventral view of sterno-pleonal cavity with G1 in situ; (D) male pleonal somites 1-4; (E)the fourth ambulatory leg. Scales $=5 \mathrm{~mm}$. Photo credit: Song-Bo Wang. 


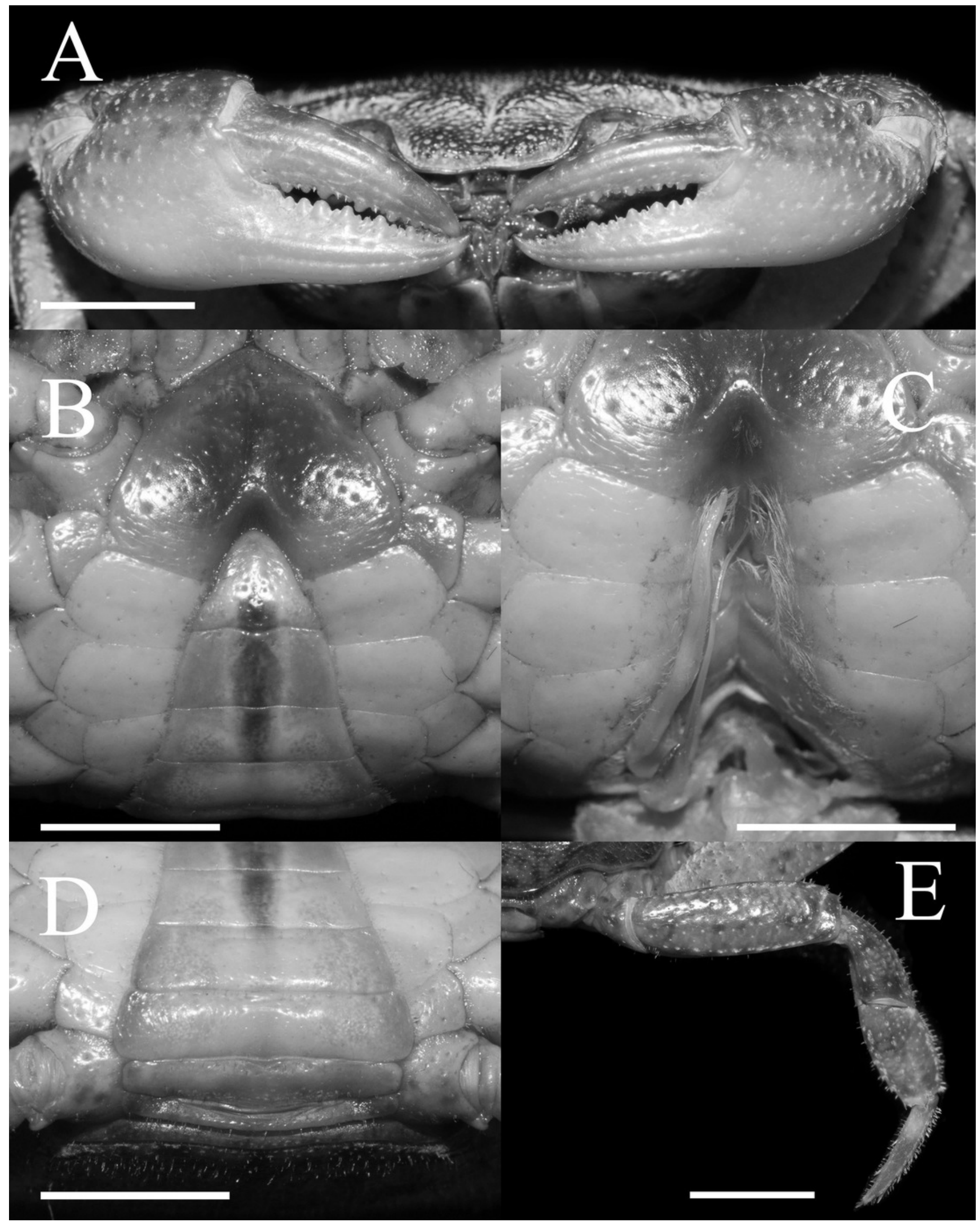


Figure 3

Qianguimon yuzhouense n. sp. Paratype female $(14.5 \times 12.3 \mathrm{~mm})($ NCU MCP 415703).

(A) overall habitus; (B) female vulvae. Scales $=5 \mathrm{~mm}$. Photo credit: Song-Bo Wang.

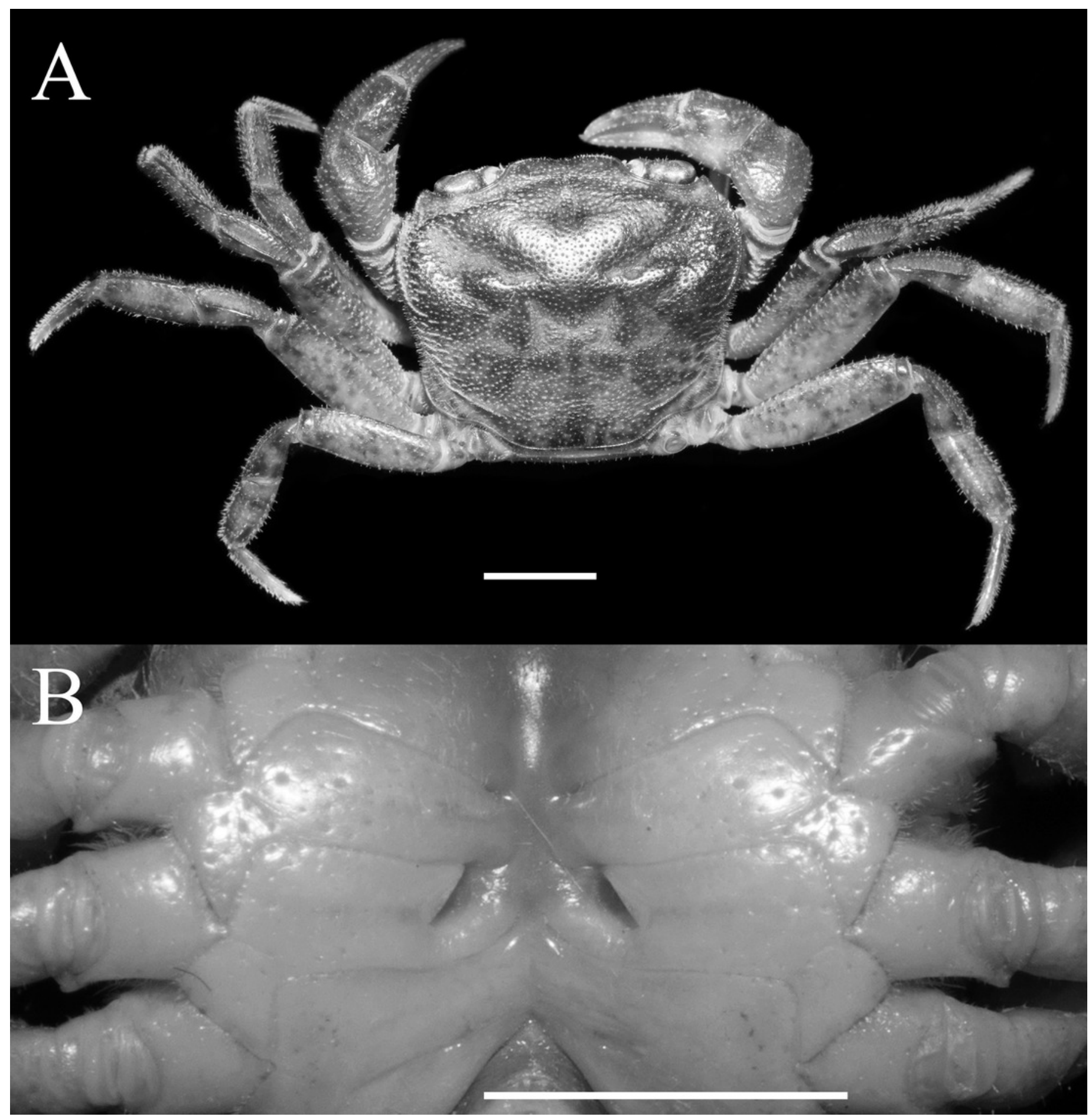


Figure 4

Gonopods of holotype.

(A) ventral view of the left $\mathrm{G1}$; (B) ventral view of the terminal segment of left $\mathrm{G1}$; (C) dorsal view of the left $\mathrm{G} 1$; (D) dorsal view of the terminal segment of left $\mathrm{Gl}$; $(E)$ ventral view of the left G2. Scales $=1 \mathrm{~mm}$. Photo credit: Song-Bo Wang.

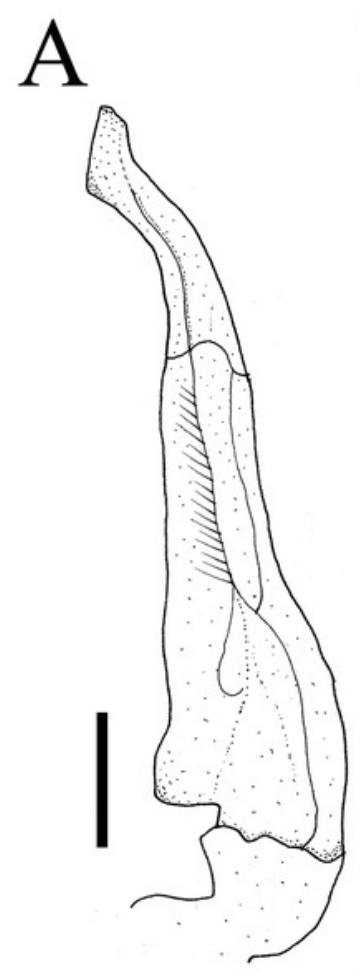

$\mathrm{B}$

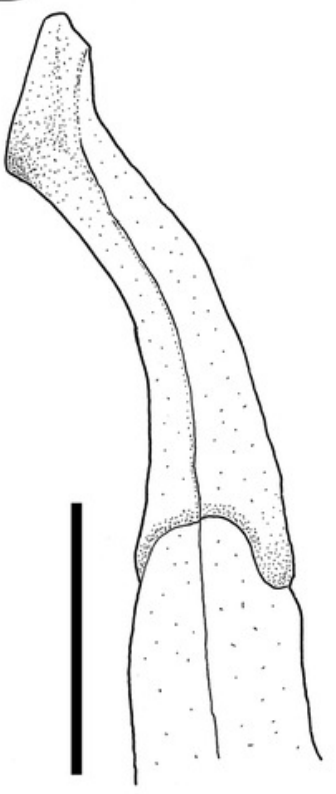

$\mathrm{C}$

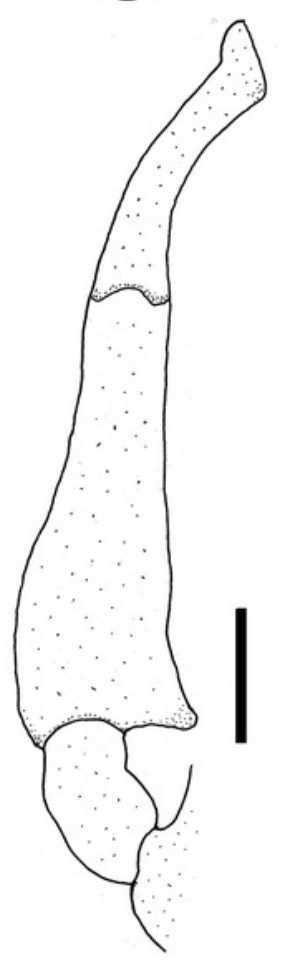

$\mathrm{E}$

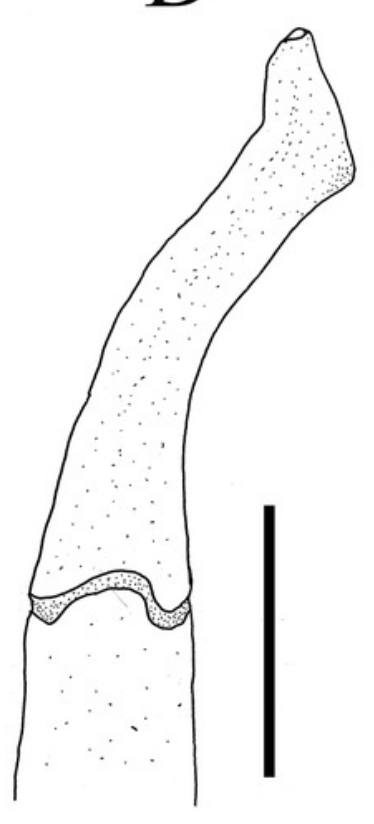

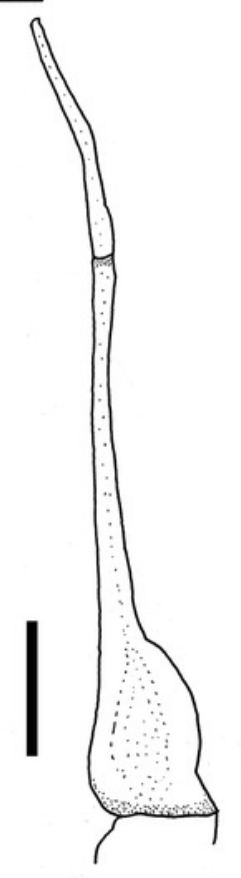




\section{Figure 5}

The left Gls of the five species of Qianguimon.

(A) Q. yuzhouense n. sp., NCU MCP 415701; (B) Q. rongxianense Wang, Huang \& Zou, 2019, NCU MCP 118401; (C) Q. aflagellum, Huang, 2018, SYSBM 0014033; (D) Q. elongatum, Huang, 2018, SYSBM 001421 dorsal view of the terminal segment of right G1; (E) Q.splendidum, Huang, 2018, SYSBM 001597. Scales $=1 \mathrm{~mm}$. Photo credit: Chao Huang.

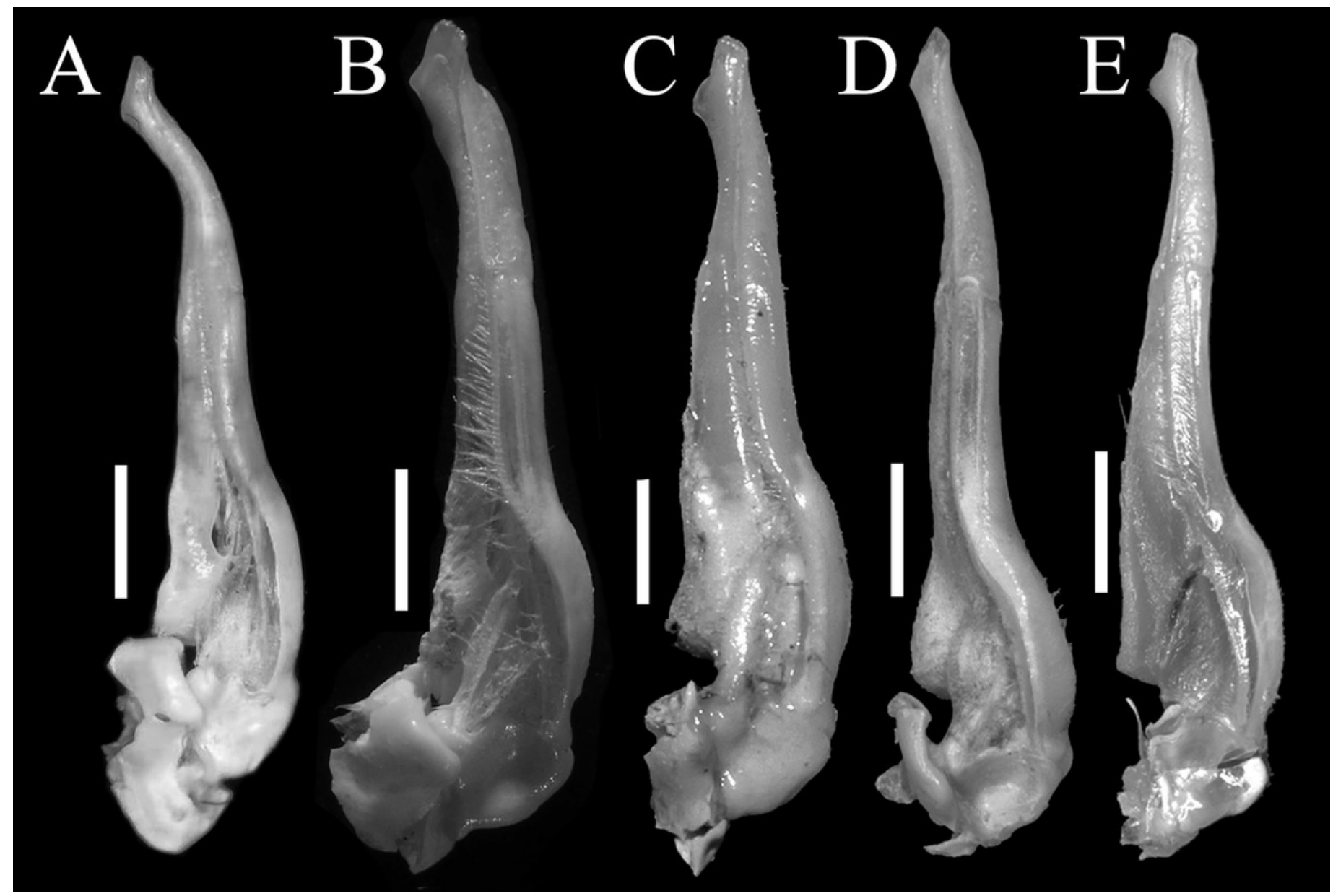


Figure 6

Habitat Environment.

( $A$ and $B$ ) color in life; (C) a burrow inhabited by the new species (indicated by circle); (D) collecting specimens by hand. Photo credit: Chao Huang.

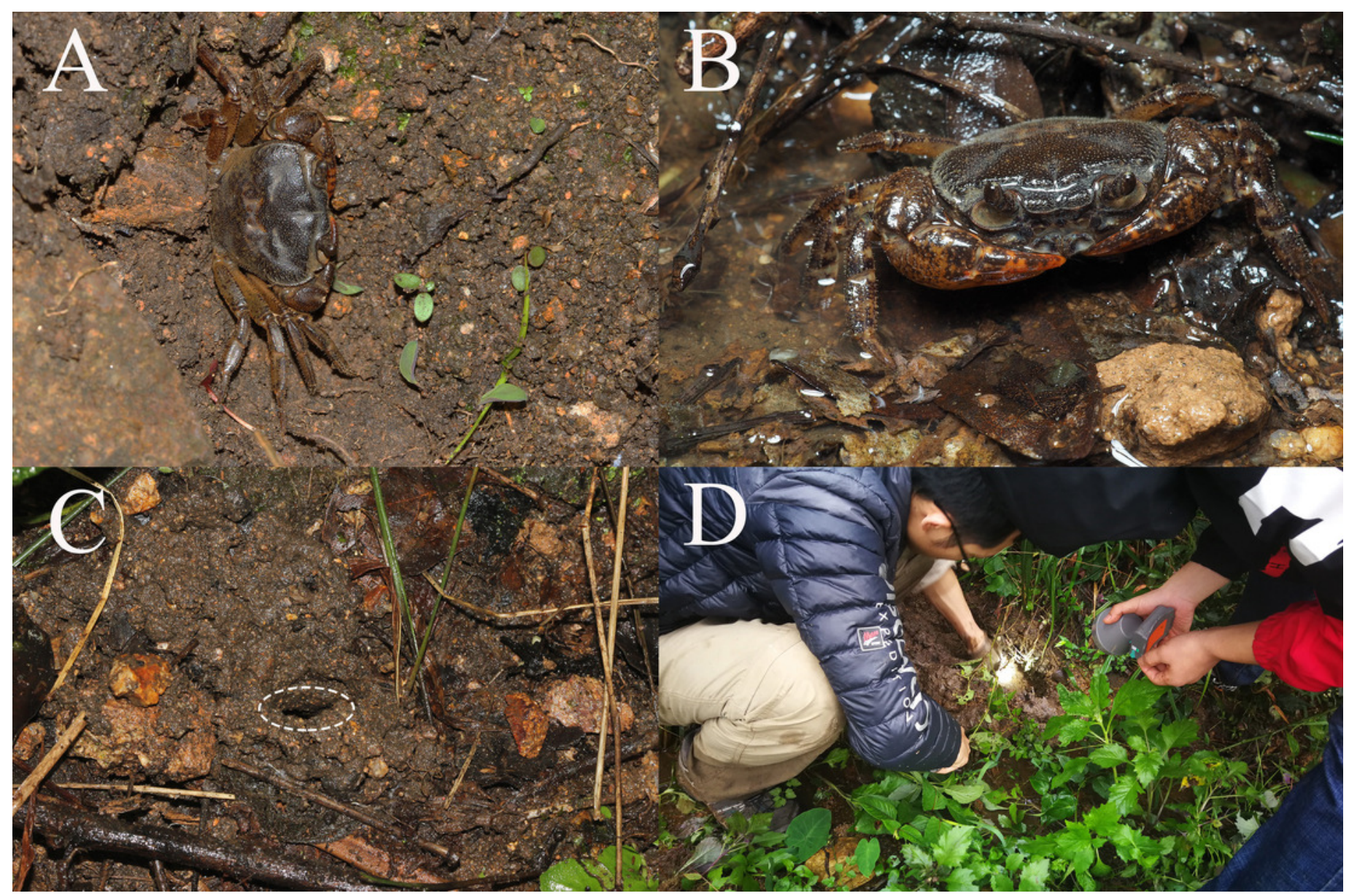


Figure 7

Phylogenetic tree.

Based on the 16S rRNA genes of the Qianguimon yuzhouense n. sp. and some other species for comparison. Topologies and branch lengths were obtained from BI analysis. Support values represented at the nodes were from BI and ML. Photo credit: Song-Bo Wang.

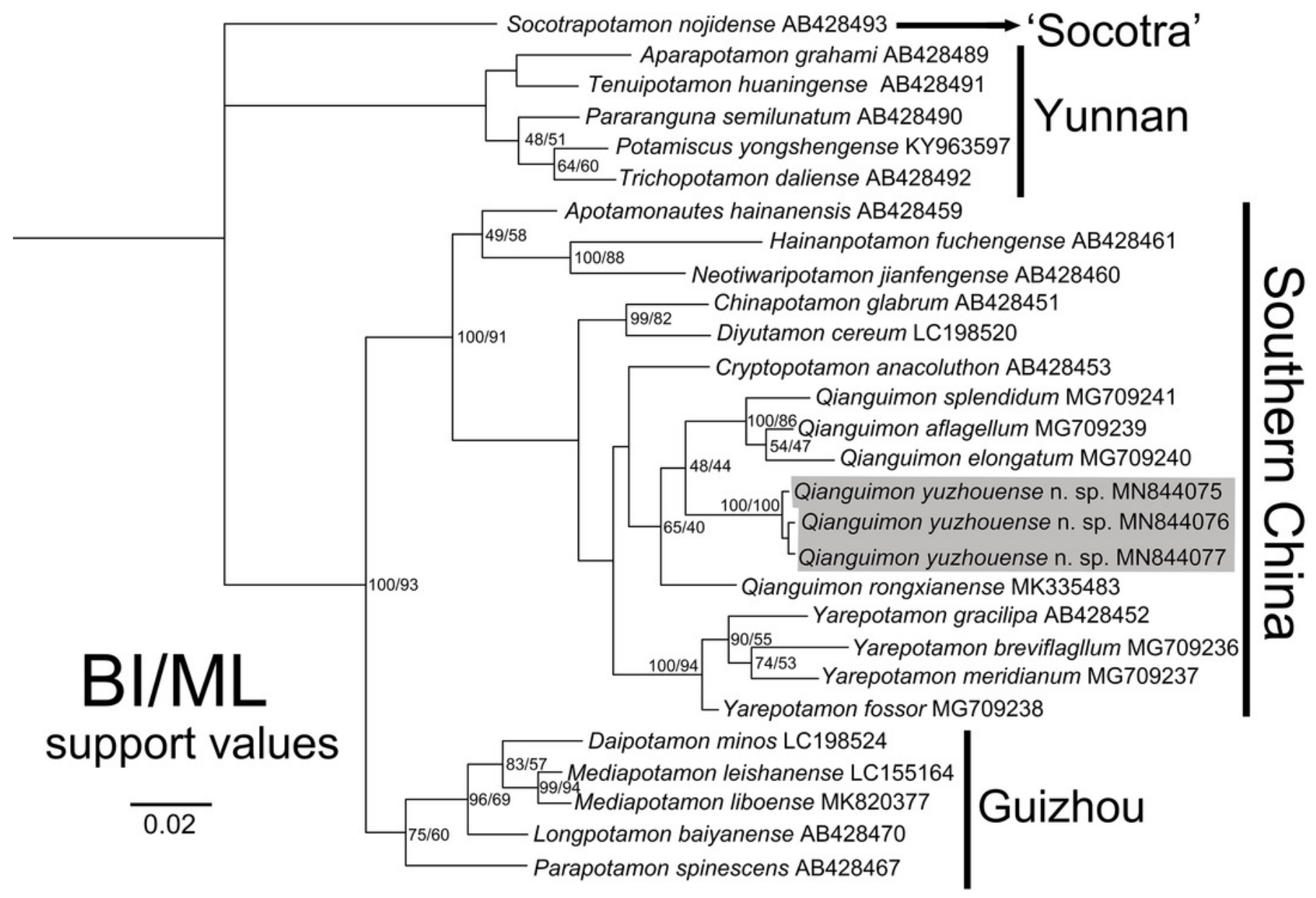




\section{Table 1 (on next page)}

GenBank accession number of the species used for phylogenetic analysis.

The $16 \mathrm{~S}$ rRNA genes of 26 species belonging to 18 genera of the subfamily Potamidae from Asia . 


\begin{tabular}{|c|c|c|c|c|}
\hline Species & $\begin{array}{l}\text { Museum } \\
\text { number }\end{array}$ & Locality & $\begin{array}{l}\text { GenBank } \\
\text { number }\end{array}$ & Reference \\
\hline $\begin{array}{l}\text { Aparapotamon grahami Rathbun, } \\
1929\end{array}$ & ZRC 0334(II) & $\begin{array}{l}\text { Yunnan, } \\
\text { China }\end{array}$ & AB428489 & Shih, Yeo \& Ng, 2009 \\
\hline $\begin{array}{l}\text { Apotamonautes hainanensis } \\
\text { Parisi, } 1916\end{array}$ & $\mathrm{ZRC}$ & $\begin{array}{l}\text { Hainan, } \\
\text { China }\end{array}$ & AB428459 & Shih, Yeo \& Ng, 2009 \\
\hline $\begin{array}{l}\text { Chinapotamon glabrum Dai, } \\
\text { Song, Li \& Liang, } 1980\end{array}$ & CAS CB & $\begin{array}{l}\text { Guangxi, } \\
\text { China }\end{array}$ & AB428451 & Shih, Yeo \& Ng, 2009 \\
\hline $\begin{array}{l}\text { Cryptopotamon anacoluthon } \\
\text { Kemp, } 1918\end{array}$ & $\begin{array}{l}\text { NCHUZOOL } \\
13122\end{array}$ & Hong Kong & AB428453 & Shih, Yeo \& Ng, 2009 \\
\hline $\begin{array}{l}\text { Daipotamon minos } \mathrm{Ng} \& \text { Trontelj, } \\
1996\end{array}$ & $\mathrm{ZRC}$ & $\begin{array}{l}\text { Guizhou, } \\
\text { China }\end{array}$ & LC198524 & Huang, Shih \& Ng, 2017 \\
\hline $\begin{array}{l}\text { Diyutamon cereum Huang, Shih \& } \\
\text { Ng, } 2017\end{array}$ & SYSBM & $\begin{array}{l}\text { Guizhou, } \\
\text { China }\end{array}$ & LC198520 & Huang, Shih \& Ng, 2017 \\
\hline $\begin{array}{l}\text { Hainanpotamon fuchengense Dai, } \\
1995\end{array}$ & $\begin{array}{l}\text { NCHUZOOL } \\
13128\end{array}$ & $\begin{array}{l}\text { Hainan, } \\
\text { China }\end{array}$ & AB428461 & Shih, Yeo \& Ng, 2009 \\
\hline $\begin{array}{l}\text { Longpotamon baiyanense Ng \& } \\
\text { Dai, } 1997\end{array}$ & $\mathrm{ZRC}$ & $\begin{array}{l}\text { Hunan, } \\
\text { China }\end{array}$ & AB428470 & Shih, Yeo \& Ng, 2009 \\
\hline $\begin{array}{l}\text { Mediapotamon leishanense Dai, } \\
1995\end{array}$ & $\begin{array}{l}\text { SYSBM } \\
001094\end{array}$ & $\begin{array}{l}\text { Guizhou, } \\
\text { China }\end{array}$ & LC155164 & Shih, Huang \& Ng, 2016 \\
\hline $\begin{array}{l}\text { Mediapotamon liboense Wang \& } \\
\text { Zhou, } 2019\end{array}$ & $\begin{array}{l}\text { NCU MCP } \\
343004\end{array}$ & $\begin{array}{l}\text { Guizhou, } \\
\text { China }\end{array}$ & MK820377 & Wang, Zhou \& Zou, 2019 \\
\hline $\begin{array}{l}\text { Neotiwaripotamon jianfengense } \\
\text { Dai \& Naiyanetr, } 1994\end{array}$ & $\begin{array}{l}\text { NCHUZOOL } \\
13127\end{array}$ & $\begin{array}{l}\text { Hainan, } \\
\text { China }\end{array}$ & AB428460 & Shih, Yeo \& Ng, 2009 \\
\hline $\begin{array}{l}\text { Parapotamon spinescens Calman, } \\
1905\end{array}$ & NCU MCP & $\begin{array}{l}\text { Yunnan, } \\
\text { China }\end{array}$ & AB428467 & Shih, Yeo \& Ng, 2009 \\
\hline $\begin{array}{l}\text { Pararanguna semilunatum Dai \& } \\
\text { Chen, } 1985\end{array}$ & $\mathrm{ZRC}$ & $\begin{array}{l}\text { Yunnan, } \\
\text { China }\end{array}$ & AB428490 & Shih, Yeo \& Ng, 2009 \\
\hline $\begin{array}{l}\text { Potamiscus yongshengense Dai \& } \\
\text { Chen, } 1985\end{array}$ & NNU150951 & $\begin{array}{l}\text { Yunnan, } \\
\text { China }\end{array}$ & KY963597 & Chu, Zhou \& Sun, 2017 \\
\hline $\begin{array}{l}\text { Qianguimon splendidum Huang, } \\
2018\end{array}$ & $\begin{array}{l}\text { SYSBM } \\
001598\end{array}$ & $\begin{array}{l}\text { Guangxi, } \\
\text { China }\end{array}$ & MG709241 & Huang, 2018 \\
\hline $\begin{array}{l}\text { Qianguimon aflagellum Dai, } \\
\text { Song, Li \& Liang, } 1980\end{array}$ & $\begin{array}{l}\text { SYSBM } \\
001404\end{array}$ & $\begin{array}{l}\text { Guangxi, } \\
\text { China }\end{array}$ & MG709239 & Huang, 2018 \\
\hline $\begin{array}{l}\text { Qianguimon elongatum Huang, } \\
2018\end{array}$ & $\begin{array}{l}\text { SYSBM } \\
001424\end{array}$ & $\begin{array}{l}\text { Guizhou, } \\
\text { China }\end{array}$ & MG709240 & Huang, 2018 \\
\hline $\begin{array}{l}\text { Qianguimon rongxianense Wang, } \\
2019\end{array}$ & $\begin{array}{l}\text { NCU MCP } \\
118401\end{array}$ & $\begin{array}{l}\text { Guangxi, } \\
\text { China }\end{array}$ & MK335483 & $\begin{array}{l}\text { Wang, Huang \& Zou, } \\
2019\end{array}$ \\
\hline
\end{tabular}




\begin{tabular}{|c|c|c|c|c|}
\hline $\begin{array}{l}\text { Socotrapotamon nojidensis Apel } \\
\text { \& Brandis, } 2000\end{array}$ & $\begin{array}{l}\text { ZRC } \\
2000.2232\end{array}$ & $\begin{array}{l}\text { Socotra, } \\
\text { Yemen }\end{array}$ & AB428493 & Shih, Yeo \& Ng, 2009 \\
\hline Tenuipotamon huaningense Dai \& & CAS CB & Yunnan, & AB428491 & Shih, Yeo \& Ng, 2009 \\
\hline Bo, 1994 & 05175 & China & & \\
\hline Trichopotamon daliense Dai \& & NCHUZOOL & Yunnan, & AB428492 & Shih, Yeo \& Ng, 2009 \\
\hline Chen, 1985 & 13130 & China & & \\
\hline Yarepotamon gracilipa Dai, Song, & $\mathrm{ZRC}$ & Guangxi, & AB428452 & Shih, Yeo \& Ng, 2009 \\
\hline Li \& Liang, 1980 & & China & & \\
\hline \multirow[t]{2}{*}{ Yarepotamon fossor Huang,2018 } & SYSBM & Guangxi, & MG709238 & Huang, 2018 \\
\hline & 001417 & China & & \\
\hline Yarepotamon breviflagllum Dai\& & SYSBM & Guangdong, & MG709236 & Huang, 2018 \\
\hline Tüerkay, 1997 & 001442 & China & & \\
\hline Yarepotamon meridianum Huang, & SYSBM & Guangdong, & MG709237 & Huang, 2018 \\
\hline 2018 & 001581 & China & & \\
\hline \multirow[t]{2}{*}{ Qianguimon yuzhouense n. sp. } & NCU MCP & Guangxi, & MN844075 & This study \\
\hline & 415701 & China & & \\
\hline \multirow[t]{2}{*}{ Qianguimon yuzhouense n. sp. } & NCU MCP & Guangxi, & MN844076 & This study \\
\hline & 415704 & China & & \\
\hline \multirow[t]{2}{*}{ Qianguimon yuzhouense $\mathrm{n} . \mathrm{sp}$. } & NCU MCP & Guangxi, & MN844077 & This study \\
\hline & 415705 & China & & \\
\hline
\end{tabular}

1 CAS CB, Chinese Academy of Sciences, Beijing, China; NCHUZOOL, Zoological Collections 2 of the Department of Life Science, National Chung Hsing University, Taichung, Taiwan; NCU 3 MCP, Department of Parasitology of the Medical College of Nanchang University, Jiangxi, 4 China; NNU, College of Life Sciences, Nanjing Normal University, Nanjing, China; SYSBM, 5 Sun Yat-sen Museum of Biology, Sun Yat-Sen University, Guangzhou, China; ZRC, Zoological 6 Reference Collection of the Raffles Museum of Biodiversity Research, National University of 7 Singapore, Singapore. 


\section{Table 2 (on next page)}

Morphological differences between the five species of Qianguimon Huang, 2018. 


\begin{tabular}{|c|c|c|c|c|c|}
\hline $\begin{array}{l}\text { Species/ } \\
\text { Character }\end{array}$ & $\begin{array}{l}\text { Q. yuzhouense } \\
\text { n.sp. }\end{array}$ & Q. rongxianense & Q. aflagellum & Q. elongatum & Q. splendidum \\
\hline Carapace & $\begin{array}{l}\text { Regions distinct, } \\
\text { surface rugged }\end{array}$ & $\begin{array}{l}\text { Regions indistinct, } \\
\text { surface generally } \\
\text { smooth }\end{array}$ & $\begin{array}{l}\text { Regions indistinct, } \\
\text { surface generally } \\
\text { smooth }\end{array}$ & $\begin{array}{l}\text { Regions indistinct, } \\
\text { surface generally } \\
\text { smooth }\end{array}$ & $\begin{array}{l}\text { Regions indistinct, } \\
\text { surface very smooth }\end{array}$ \\
\hline $\begin{array}{l}\text { Flagellum of } \\
\text { exopod of third } \\
\text { maxilliped }\end{array}$ & $\begin{array}{l}\text { Very short to } \\
\text { absent }\end{array}$ & Short length & Very short to absent & Absent & Absent \\
\hline G1 in situ & $\begin{array}{l}\text { Exceeding } \\
\text { sternites } 4 / 5 \\
\text { suture }\end{array}$ & $\begin{array}{l}\text { Not reaching sternites } \\
4 / 5 \text { suture }\end{array}$ & $\begin{array}{l}\text { Reaching to sternites } \\
4 / 5 \text { suture }\end{array}$ & $\begin{array}{l}\text { Well exceeding } \\
\text { sternites } 4 / 5 \text { suture }\end{array}$ & $\begin{array}{l}\text { Exceeding sternites } \\
4 / 5 \text { suture }\end{array}$ \\
\hline $\begin{array}{l}\text { G1 and the } \\
\text { shape of sub- } \\
\text { distal projection }\end{array}$ & $\begin{array}{l}\text { Very slender, } \\
\text { bend inward } \\
\text { about } 45^{\circ} \text {, blunt }\end{array}$ & $\begin{array}{l}\text { Generally slender, } \\
\text { bend inward about } 20^{\circ} \text {, } \\
\text { large triangular }\end{array}$ & $\begin{array}{l}\text { Generally slender, } \\
\text { upward straightly, } \\
\text { large triangular }\end{array}$ & $\begin{array}{l}\text { Very slender, bend } \\
\text { inward about } 20^{\circ} \text {, } \\
\text { blunt }\end{array}$ & $\begin{array}{l}\text { Very slender, } \\
\text { upward straightly, } \\
\text { large triangular }\end{array}$ \\
\hline $\begin{array}{l}\text { Opening of } \\
\text { female vulvae }\end{array}$ & $\begin{array}{l}\text { Inward and } \\
\text { deflect about } 45^{\circ}\end{array}$ & $\begin{array}{l}\text { Inward and deflect } \\
\text { about } 20^{\circ}\end{array}$ & $\begin{array}{l}\text { Inward without } \\
\text { deflect }\end{array}$ & $\begin{array}{l}\text { Inward without } \\
\text { deflect }\end{array}$ & $\begin{array}{l}\text { Inward and deflect } \\
\text { about } 20^{\circ}\end{array}$ \\
\hline
\end{tabular}




\section{Table 3(on next page)}

K2P divergences between sequences of the five species from Qianguimon Huang, 2018. 


\begin{tabular}{|c|c|c|c|c|c|c|c|}
\hline & 1 & 2 & 3 & 4 & 5 & 6 & 7 \\
\hline \multicolumn{8}{|l|}{ 1. Q. splendidum MG709241 } \\
\hline 2. Q. aflagellum MG709239 & 0.020900 & & & & & & \\
\hline 3. Q. elongatum MG709240 & 0.032785 & 0.020900 & & & & & \\
\hline 4. Q. rongxianense $\mathrm{MK} 335483$ & 0.039934 & 0.037587 & 0.037507 & & & & \\
\hline 5. Q. yuzhouense n.sp. MN844075 & 0.040026 & 0.037587 & 0.037507 & 0.040084 & & & \\
\hline 6. Q. yuzhouense n.sp. MN844076 & 0.040026 & 0.037587 & 0.037507 & 0.040084 & 0.000000 & & \\
\hline 7. Q. yuzhouense n.sp. MN844077 & 0.040026 & 0.037587 & 0.037507 & 0.040084 & 0.000000 & 0.000000 & \\
\hline
\end{tabular}

